\title{
The Interactions among the Heavy Metals in Soils and in Weeds and Their Antioxidant Capacity under the Mining Activities in Thai Nguyen Province, Vietnam
}

\author{
Ngoc-Lien Nguyen, ${ }^{1}$ Cam-Tu Vu $\left(\mathbb{D},{ }^{2}\right.$ Hien-Minh To, ${ }^{1}$ Hoang-Nam Pham $\left(\mathbb{D},{ }^{1}\right.$ \\ Hai-Dang Nguyen $\left(\mathbb{1},{ }^{3}\right.$ Tien-Dat Nguyen $\left(\mathbb{1},{ }^{4}\right.$ and Kieu-Oanh Nguyen Thi $\mathbb{1}^{1}$ \\ ${ }^{1}$ Department of Life Sciences, University of Science and Technology of Hanoi, Vietnam Academy of Science and Technology, \\ 18-Hoang Quoc Viet, Cau Giay, Hanoi, Vietnam \\ ${ }^{2}$ Department of Water-Environment-Oceanography, University of Science and Technology of Hanoi, \\ Vietnam Academy of Science and Technology, 18-Hoang Quoc Viet, Cau Giay, Hanoi, Vietnam \\ ${ }^{3}$ University of Science and Technology of Hanoi, Vietnam Academy of Science and Technology, 18-Hoang Quoc Viet, Cau Giay, \\ Hanoi, Vietnam \\ ${ }^{4}$ Center for Research and Technology Transfer, Vietnam Academy of Science and Technology, 18-Hoang Quoc Viet, Cau Giay, \\ Hanoi, Vietnam
}

Correspondence should be addressed to Kieu-Oanh Nguyen Thi; nguyen.thi.kieu.oanh0711@gmail.com

Received 20 August 2020; Accepted 15 October 2020; Published 31 October 2020

Academic Editor: Agnieszka Saeid

Copyright (c) 2020 Ngoc-Lien Nguyen et al. This is an open access article distributed under the Creative Commons Attribution License, which permits unrestricted use, distribution, and reproduction in any medium, provided the original work is properly cited.

\begin{abstract}
In this study, the relationship between heavy metals (HMs) concentrations in soils and several weeds including Cyclosorus parasiticus, Dicranopteris linearis, Pityrogramma calomelanos, and Pteris vittata in three mining sites (Cam Gia (Thai Nguyen city), Tan Long (Dong Hy district), and Ha Thuong (Dai Tu district)) in Thai Nguyen province, Vietnam, have been investigated. The levels of $\mathrm{HMs}$ varied among soil origins and showed the contaminations of $\mathrm{As}, \mathrm{Cu}$, and $\mathrm{Pb}$ in soil samples collected in Dong Hy and Dai Tu districts. In addition, the HM distribution and cocontamination phenomena in different soils significantly affected the HM residues and transportation abilities into different species as well as tissues. Moreover, based on the analysis of bioaccumulation factor (BF) and translocation factor (TF), C. parasiticus and D. linearis were found potentially for phytoextraction by roots, while $P$. calomelanos and $P$. vittata were suitable for hyperaccumulation in shoots and leaves. Consequently, the strongest antioxidant property by 1,1-diphenyl-2-picrylhydrazyl (DPPH) and superoxide anion (SRSA) radical scavenging assays were demonstrated in the methanol root extracts of C. parasiticus and P. vittata, respectively. In conclusion, the correlation among HM in soils and tissues with antioxidant property allows us to hypothesize that the presence of these elements can enhance the antioxidant activity of plant extracts, suggesting to apply the weeds in phytoremediation as well as in phytomedicine.
\end{abstract}

\section{Introduction}

Heavy-metal (HM) pollution is raising alarms since they can cause massive development in industrialization and mining, especially in developing countries. Although HM explorations bring many economic benefits, the serious pollution by exceeding HMs in the soil and water occurs as a matter of obsolete technology or the lack of systematic mining process and preliminary treatment. In the world, up to $80 \%$ of industrial polluted sites, which cause health-related threats and $\mathrm{HM}$ pollutants such as $\mathrm{As}, \mathrm{Pb}, \mathrm{Cd}, \mathrm{Zn}$, are listed in the top 12 red-flag contaminants [1]. In Northern Vietnam, several mining areas in Thai Nguyen province are famous for their rich mineral resources of $\mathrm{Fe}, \mathrm{Ti}, \mathrm{Zn}, \mathrm{Cu}, \mathrm{Pb}$, ferrous, and nonferrous ores. The studies of soil analysis in these regions reportedly contained several HMs contaminated sites in the scenario of the foreign firm's accelerating exploitation and outdated manual mining technology [2]. 
Analysis of soil samples in the $\mathrm{Pb}-\mathrm{Zn}$ ore Dong $\mathrm{Hy}$, Thai Nguyen showed concentrations of the elements $\mathrm{Pb}, \mathrm{Zn}, \mathrm{Cd}$, and As that exceeded many times the permissible standards $[3,4]$. In Dai Tu district, mining activities at local craft have created a significant amount of waste tailings and waste rock. Results of several waste rock samples have shown that the average As levels reached $5000 \mathrm{mg} / \mathrm{kg}$. Other HM contents in the samples are also very high (Cu $1260 \mathrm{mg} / \mathrm{kg} ; \mathrm{Pb} 105 \mathrm{mg}$ / $\mathrm{kg}$; Cd $0.5 \mathrm{mg} / \mathrm{kg}$; Se $17 \mathrm{mg} / \mathrm{kg}$ ) which indicates that there is cocontamination of several HMs in a site [5]. Since As contaminated sites have been proved to simultaneously exist with high levels of $\mathrm{Cu}, \mathrm{Cr}, \mathrm{Cd}, \mathrm{Pb}$, and $\mathrm{Zn}[1,6]$, the exceeding HMs distributed to agricultural soil (paddy, tea, and forest fields) surrounding tin and tungsten mines in Dai Tu district, present at up to $1000 \mathrm{mg} / \mathrm{kg}$ for As, $300 \mathrm{mg} / \mathrm{kg}$ for $\mathrm{Cu}$, and abnormal high level of other HMs including $\mathrm{Cd}, \mathrm{Zn}$, $\mathrm{Pb}, \mathrm{Mn}$. Other soil analysis in the mining sites of Northern Vietnam also shows cocontamination of $\mathrm{Pb}, \mathrm{As}, \mathrm{Zn}, \mathrm{Cd}, \mathrm{Cu}$ with the factors of $314,2990,280,28,11$ times, respectively, higher the level of Vietnamese standard for mining soil (QCVN 03-MT: 2015/BTNMT 2015) [7, 8].

Excess of HMs in the soil can cause phytotoxic effects in plants in several ways including the excessive production of free radicals and reactive oxygen species (ROS). ROS being highly unstable could play a dual role: (i) damage cellular components and (ii) act as an important secondary messenger for inducing plant defense systems, which affect plant growth and biomass [9]. To counteract this damage, plants are equipped with enzymatic and nonenzymatic defense mechanisms. Several plants are known as hyperaccumulators since they are capable of growing in soils with very high concentrations of metals, absorbing these metals through their roots, and concentrating extremely high levels of metals in their tissues $[10,11]$. These hyperaccumulators possess several antioxidative defense systems to scavenge toxic free radicals in order to protect themselves from the oxidative stress that is caused by HMs.

Interestingly, many hyperaccumulators belong to pteridophytes that are important plants from a phylogenetic and evolutionary perspective [12]. Botanically, these temperate-thriving plants were wild and many of them were weeds a thousand years ago. As these plants have survived since Paleozoic times, pteridophytes have survived more disruptive changes in the environment than any other vascular plants. This can be explained as the reason why these ferns were considered as hyperaccumulators. C. parasiticus, D. linearis, P. calomelanos, and P. vittata are four ferns that dominate in mining sites in Thai Nguyen province, Vietnam, in which the two latter weeds, $P$. calomelanos, and $P$. vittata, have been reported as strong arsenic hyperaccumulators [6, 13-15].

In order to explore the relationship between heavy-metal concentrations in the metalliferous soils on the heavy-metal uptake, capabilities of the corresponding local several dominant ferns including C. parasiticus, D. linearis, $P$. calomelanos, and $P$. vittata collected in the three mining sites in Thai Nguyen province, Vietnam, were evaluated for their antioxidant activity via 1,1-diphenyl-2-picrylhydrazyl $(\mathrm{DPPH})$ and superoxide anion (SRSA) radical scavenging assays. The screening results can be a good start for further studies of the antioxidants which can be applied in the health industry. Consequently, the investigation of HMs contaminated levels can be useful for applying some methods in order to reduce pollution and/or protect the environment. We also try to find out the relationship between antioxidant activity of plants and HMs levels in soil in order to incorporate the environment purpose and natural sources valorization.

\section{Materials and Methods}

2.1. Chemicals. Hydrochloric acid, $\mathrm{HCl}(36.5-38 \%)$, nitric acid, $\mathrm{HNO} 3$ (63\%), sulfuric acid, $\mathrm{H} 2 \mathrm{SO} 4$ (98\%), HClO4, $\mathrm{DPPH}$, methanol (MeOH, HPLC grade), ascorbic acid (>99\%), catechin, and xanthine were purchased from Sigma Aldrich (Taufkirchen, Germany) in analytical grade. Ultrapure water (UPW) was prepared using a Millipore (MilliQ) purification system (Millipore $\mathrm{GmbH}$, Schwalbach, Germany, $18.2 \mathrm{M} \Omega \cdot \mathrm{cm}, \mathrm{TOC}<2 \mu \mathrm{g} / \mathrm{L})$.

2.2. Soil and Plant Sampling. Four dominant plant species were found at three mine sites that were described in Table S1. C. parasiticus (Thelypteridaceae) were collected at the Campus of Thai Nguyen Iron and Steel Corporation, Cam Gia Ward, Thai Nguyen City, Thai Nguyen province. Two other weeds, D. linearis (Gleicheniaceae) and P. calomelanos (Adiantaceae), were collected in Ha Thuong commune, Dai Tu district, Thai Nguyen province. P. vittata (Pteridaceae) was collected in Hich village, Tan Long commune, Dong Hy district, Thai Nguyen province, Vietnam. All plant samples were identified by Dr. Nguyen The Cuong, Institute of Ecology and Biological Resources, Vietnam Academy of Science and Technology. The voucher of specimens was deposited in the Department of Life Sciences, University of Science and Technology of Hanoi. The corresponding soil samples were dug in the rhizospheric area (up to $20 \mathrm{~cm}$ depth from the topsoil and $10 \mathrm{~cm}$ diameter from plant position) of the collected plants. All plant and soil samples were collected under dry weather conditions, March $9^{\text {th }}, 2015$, stored in polyethylene bags, labeled appropriately.

For sample preparation, each plant was divided into 3 parts: leaves, shoots, and roots. All plant tissues were washed by tap water to remove all dust and soil residues and then rinsed by UPW. All parts were cut down into smaller parts and dried in the oven at $55^{\circ} \mathrm{C}$ for $48 \mathrm{~h}$ to achieve the stable weight of samples. Similarly, soil samples were also prepared in the same manner of drying in the oven at $105^{\circ} \mathrm{C}$ for $24 \mathrm{~h}$ until constant weight after removing all the moisture. Then, plant and soil samples were crushed by using the clean and dry mortar, followed by screening steps using $2 \mathrm{~mm}$ and $0.18 \mathrm{~mm}$ sieves, respectively. The prepared samples were finally stored at $-80^{\circ} \mathrm{C}$ until analysis.

2.3. Atomic Absorption Spectrometry (AAS) Technique. To determine the $\mathrm{Pb}, \mathrm{Cu}, \mathrm{Cd}$, and $\mathrm{Zn}$ concentrations in soil samples: $15 \mathrm{~mL} \mathrm{HCl} \mathrm{37 \%} \mathrm{and} 5 \mathrm{~mL}$ HNO 3 65\% were added to $2 \mathrm{~g}$ of dried and ground soil samples which were contained in $50 \mathrm{~mL}$ baker. The mixtures were digested on a hot plate at 
$95^{\circ} \mathrm{C}$ until getting the transparent solutions and then let to room temperature and prepared for analysis. Especially for As analysis: $5 \mathrm{~mL} \mathrm{HNO} 365 \%$ was added to $2 \mathrm{~g}$ of prepared soil samples, and then the mixture was treated in a microwave oven for $40 \mathrm{~min}$. The sample was cooled down to room temperature. After the treatment, all five HMs in soil samples were formed in the dissolved solution and filtered through $0.45 \mu \mathrm{m}$ cellulose acetate membrane (Whatman, England) and ready for analysis.

In order to determine the HM concentration in the plants, each $0.5 \mathrm{~g}$ of each tissue powder was digested by a mixture including $3 \mathrm{~mL}$ concentrated $\mathrm{H} 2 \mathrm{SO} 498 \%, 0.5 \mathrm{~mL}$ $\mathrm{HClO} 4$, and $10 \mathrm{~mL}$ of concentrated $\mathrm{HNO}$. The mixture was then heated in the oven at temperature between 150 and $-200^{\circ} \mathrm{C}$ for at least $120 \mathrm{~min}$. The operation was repeated until the digested solutions became clear and homogenous. Then, the obtained solution was normed up to $25 \mathrm{~mL}$ in the Erlenmeyer flask. All the final sample solutions were shaken well at $180 \mathrm{rpm}$ on $\mathrm{IKA}^{\circledR}{ }^{\circledR}$ C-MAG HS 4 magnetic stirrer (Cologne, Germany) for $20 \mathrm{~min}$, filtered by $0.45 \mu \mathrm{m}$ cellulose acetate membrane to remove all the particulars, and then diluted to $25 \mathrm{~mL}$ for measuring $\mathrm{Cu}, \mathrm{Pb}, \mathrm{Zn}, \mathrm{Cd}$ concentration. For As concentration measurement, $15 \mathrm{~mL}$ of the solution on the surface was made up with $10 \mathrm{~mL}$ UPW to get finally $25 \mathrm{~mL}$ for measuring.

All measurements were done in triplicate by the Atomic Absorption Spectrometry method, proposed by APHA (1995) based on the Varian 280FS and AA280Z (Australia). The results were reported by the average values with relative standard deviation (\% RSD) lower than $10 \%$.

2.4. DPPH Scavenging Assay. In order to evaluate the antioxidant activity of plant tissues, approximately $5.0 \mathrm{~g}$ of each tissue powder was extracted with $\mathrm{MeOH}$ solution $(100 \mathrm{~mL} \times 3$ times) at room temperature in an ultrasonic bath Skymen JP-008 (Guangdong, China). The combined extracts were concentrated in Buchi Rotavapor (Flawil, Switzerland) to obtain crude extracts.

The DPPH radical scavenging capacity was evaluated according to the previously described method [16]. Briefly, two concentrations of $100 \mu \mathrm{g} / \mathrm{mL}$ and $500 \mu \mathrm{g} / \mathrm{mL}$ of crude extracts dissolved in dimethyl sulfoxide $(5 \mu \mathrm{l})$ were added to $195 \mu \mathrm{l} \mathrm{DPPH}$ solution $(150 \mathrm{mM})$ in 96 -well plates. The mixed solution was incubated at room temperature for $30 \mathrm{~min}$. Then the absorbance of the reaction mixture was measured at $517 \mathrm{~nm}$ on a microplate reader $\mathrm{iMark}^{\mathrm{TM}}$ (BioRad, California, USA). Ascorbic acid was used as a positive control (SC $91.3 \%$ at $100 \mu \mathrm{g} / \mathrm{mL}$ ). The differences in absorbance between the test sample and the blank (DPPH in $\mathrm{MeOH}$ ) was calculated and expressed as (\%) scavenging capacity:

$$
\operatorname{SC}(\%)=\left(\frac{(\mathrm{Ab}-\mathrm{As})}{\mathrm{Ab}}\right) \times 100,
$$

where As is the absorbance of the test sample and $\mathrm{Ab}$ is the absorbance of the blank. Samples with SC values above 50\% were considered to be active.
2.5. Superoxide Anion Radical Scavenging Assay. The superoxide anion scavenging activity was measured based on the described method [17]. In this experiment, crude extracts were prepared at 2 concentrations as $100 \mu \mathrm{g} / \mathrm{mL}$ and $500 \mu \mathrm{g} /$ $\mathrm{mL}$ in DMSO. The standard reaction mixture in a final volume of $1 \mathrm{~mL}$ contained $10 \mu \mathrm{L}$ of sample solution, $490 \mu \mathrm{L}$ of xanthine ( $1 \mathrm{mM}$; in potassium phosphate buffer $0.1 \mathrm{M}, \mathrm{pH}$ $7.8)$, and $490 \mu \mathrm{L}$ of NBT $(0.4 \mathrm{mM}$, in potassium phosphate buffer $0.1 \mathrm{M}, \mathrm{pH} 7.8$ ). The reaction was initiated by the addition of $10 \mu \mathrm{L}$ of xanthine oxidase. Incubation at room temperature for 20 minutes and the samples' absorbance was read at $560 \mathrm{~nm}$ by using microplate reader iMark ${ }^{\mathrm{TM}}$ (BioRad, California, USA). Catechin was used as standard control (positive sample) and the blank well without sample was used as a negative sample. All experiments were performed in triplicate and the reported results are the averages of three independent measurements.

Superoxide radical scavenging activity (SRSA) is calculated by the following equation:

$$
\operatorname{SC}(\%)=\left(\frac{(A c-A s)}{(A c-A b)}\right) \times 100 .
$$

Ac is the absorbance of the positive sample, As is the absorbance of the test sample, and $\mathrm{Ab}$ is the absorbance of the negative sample. Samples with SC values above $50 \%$ were considered to be active.

2.6. Statistical Analysis. Statistics were performed in $\mathrm{R}$ version 3.5.3 [18]. Data was normalized by taking their logarithm base 10. In order to discriminate the accumulation ability of different species, the principal component analysis (PCA) was done by PCA and dudi.pca function in FactoMineR, factoextra 1.0.7, and ade4 R-package $[19,20]$. To evaluate the effect of environmental factors (HM in soils) on the accumulation of HM in the plants, a function envfit in vegan 2.5-6 R-package was used [21]. The correlation between the HM concentrations in soil and plants with antioxidant activities was calculated and visualized by Performance Analytics R-package [22].

\section{Results and Discussion}

3.1. HMs Level in Soil. Five HMs $\mathrm{As}, \mathrm{Cd}, \mathrm{Zn}, \mathrm{Pb}$, and $\mathrm{Cu}$ were quantified in 25 soil samples collected at the same positions with 25 plant samples including 5 samples of $C$. parasiticus (in Thai Nguyen city), 6 samples for each type of $D$. linearis and P. calomelanos plants (in Dai Tu district), and 8 samples of P. vittata (in Dong Hy district). According to each sampling station, the sample abbreviation was used interchangeably for the respective soil and plant samples.

Table 1 shows the highest $\mathrm{As}, \mathrm{Zn}, \mathrm{Pb}$, and $\mathrm{Cd}$ concentrations in $P$. vittata correspondent soil while the most concentration of $\mathrm{Cu}$ was found in the soil growing $C$. parasiticus plant. According to the Vietnam National regulations on the allowable limits of HMs in the soils [7] where the maximum allowable limits of $\mathrm{As}, \mathrm{Zn}, \mathrm{Pb}, \mathrm{Cu}$, and $\mathrm{Cd}$ in industrial soils are $25 ; 300 ; 300 ; 300$, and $10 \mathrm{mg} / \mathrm{kg}$, respectively. It was investigated that soil samples collected in 
TABle 1: The average of five $\mathrm{HMs}(\mathrm{As}, \mathrm{Zn}, \mathrm{Pb}, \mathrm{Cd}$, and $\mathrm{Cu}$ ) concentrations (in $\mathrm{mg} / \mathrm{kg}$ ) of soil samples corresponding to 4 plant species.

\begin{tabular}{lccccc}
\hline Correspondence & As & $\mathrm{Zn}$ & $\mathrm{Pb}$ & $\mathrm{Cd}$ & $\mathrm{Cu}$ \\
\hline C. parasiticus & $9.31 \pm 4.21$ & $108 \pm 31.9$ & $307 \pm 138$ & $1.98 \pm 0.70$ & $171 \pm 10.0$ \\
D. linearis & $2.54 \pm 0.45$ & $84.1 \pm 19.4$ & $206 \pm 56.6$ & $0.81 \pm 0.82$ & $453 \pm 313$ \\
P. calomelanos & $2.92 \pm 0.98$ & $64.3 \pm 15.4$ & $239 \pm 66.9$ & $0.38 \pm 0.16$ & $338 \pm 102$ \\
P. vittata & $53.9 \pm 13.9$ & $265 \pm 111$ & $450 \pm 248$ & $2.34 \pm 1.46$ & $11.2 \pm 8.06$ \\
\hline
\end{tabular}

Dong Hy district (P. vittata corresponding soil) were contaminated by both $\mathrm{As}$ and $\mathrm{Pb}$, whereas soils from Dai Tu was contaminated with $\mathrm{Cu}$. Soils from Cam Gia, Thai Nguyen city, witnessed the $\mathrm{Pb}$ pollution. Significantly, there were no observations of $\mathrm{Zn}$ and $\mathrm{Cd}$ contaminations in all soil samples collected from different sampling sites.

It is found that the distribution of HMs in soils was following the different soil origins and plant bioaccumulation and/or absorption [23]. To understand more this phenomenon, the principal component analysis (PCA) revealed the difference among the HM levels of three locations where 25 soil samples were collected by distinguishing $P$. vittata, D. linearis, $P$. calomelanos, and $C$. parasiticus zones (Figure 1). The first two axes of the PCA explained $66.4 \%$ of the variance. The ordination arrow represents the dominance of $\mathrm{As}$ and $\mathrm{Zn}$ in the soil samples collected in the rhizosphere of $P$. vittata in Dong $\mathrm{Hy}$ district. More $\mathrm{Pb}$ and $\mathrm{Cd}$ than other HMs were distributed in soils sampled in Dong Hy district and Thai Nguyen city, while $\mathrm{Cu}$ significantly existed in soils collected in Dai Tu district. These distributions of HMs in soils have thus corresponded to their detected concentration in different soils (Table 1). In addition, the arrow direction of vectors, which represented the distribution tendency of HMs according to soil samples, were also indicated for the cocontamination relationship between HMs in the soils. $\mathrm{Cu}$ vectors tend to contradict the vectors of other metals, indicating that $\mathrm{Cu}$ has less ability to coaccumulate concurrently with other metals in the soil. This was identified more clearly based on the Spearman index (Figure S1) when the indices representing the correlation between $\mathrm{Cu}$ and other metals were always very low (from -0.76 to -0.36). This phenomenon can be explained by higher solubility and leachability of $\mathrm{Cu}$ at the ideal soil $\mathrm{pH}$ of 6.0-6.5, compared to other HMs [24]. In contrast, Cd appeared to have a stronger correlation in soil accumulation with other metals, except $\mathrm{Cu}$, while the lowest concentrations of $\mathrm{Cd}$ were often found in all soil samples (Table 1). Consequently, the Spearman indices indicating the cocontamination between $\mathrm{Cd}$ and other HMs following the order $\mathrm{Zn}(0.76)>\mathrm{As}(0.59)>\mathrm{Pb}(0.37)$. This could be partly clarified for the highest concentrations of $\mathrm{Zn}, \mathrm{As}, \mathrm{Pb}$, and $\mathrm{Cd}$ were found in Dong Hy soil as previous investigation (Table 1). Also, $\mathrm{Pb}$ had significant cocontamination with $\mathrm{As}$ and $\mathrm{Zn}$ in soil following Spearman indices of 0.39 and 0.51 , respectively, confirming for high abilities of $\mathrm{Zn}$, As, and $\mathrm{Pb}$ accumulations in soils corresponding to $P$. vittata plant. The analysis results, therefore, presented the significant effects of cocontaminations between soil origins and the HM residences in those soils.
3.2. HMs Levels in Plant Tissues. The statistical description of HM concentration (in $\mathrm{mg} / \mathrm{kg}$ ) in 75 plant tissue samples was summarized by the average concentration with standard deviation. For each HM, the bioaccumulation factor (BF) was calculated by the ratio between the HM concentration in tissue and those in corresponding soil which is described as the ability of plants for elemental accumulation from the substrate. The efficiency of phytoremediation can be quantified by calculating the translocation factor (TF). This index expresses the capacity of a plant to store the HMs in its upper part, which is defined as the ratio of metal concentration in the upper part to that in the roots [25].

The total concentration of selected metals as well as BF and TF indices in plant roots, shoots, and leaves is shown in Table 2. In plant roots, the highest $\mathrm{As}, \mathrm{Pb}$, and $\mathrm{Zn}$ concentrations were found in P. vittata, whereas the most $\mathrm{Cu}$ concentration was measured in $P$. calomelanos. The large amounts of $\mathrm{As}, \mathrm{Pb}, \mathrm{Zn}$, and $\mathrm{Cu}$ found in plant roots of $P$. vittata and $P$. calomelanos could be explained by the high level of these metal concentrations detected in the soils where corresponding plants were cultivated (Table 1). On the other side, there was no significant difference in $\mathrm{Cd}$ concentration in the roots of 4 plants. This correlated to the low level of $\mathrm{Cd}$ found in all corresponding soils (Table 1). On average, the HM concentrations in the roots were much higher than those in the leaves and shoots, implying that fewer HMs were translocated into leaves and shoots for all four species.

In plant shoots, the As concentration ranged from $1.19 \pm 0.9 \mathrm{mg} / \mathrm{kg}$ (in C. parasiticus) to $331 \pm 75.3 \mathrm{mg} / \mathrm{kg}$ (in $P$. vittata). The total concentration $(\mathrm{mg} / \mathrm{kg}$ ) of $\mathrm{Cu}, \mathrm{Pb}$, and $\mathrm{Zn}$ in plant shoots varied significantly, with the highest values being $59.1 \pm 15.3$ (in P. calomelanos), $65.4 \pm 18.3$ (in P. vittata), and $54.2 \pm 22.2$ (in P. vittata), respectively. Similarly, in the case of metals accumulation in leaves, higher metals concentrations of $\mathrm{As}, \mathrm{Cu}, \mathrm{Pb}$, and $\mathrm{Zn}$ were found in plant leaves of P. vittata and P. calomelanos. On the other side, according to different plant types, a similar distribution tendency of measured Cd concentrations was found in plant roots and shoots, and the lower metals concentrations were often found in all tissues of C. parasiticus and D. linearis compared to other ones. It could be seen that the distribution of metal concentration in plant tissues varied greatly among plant species and had a significant correlation with HM content in soils from different sampling sites.

Moreover, the bioaccumulation factor (BF) indicates the ability of metals stored in plant tissues compared to soil [26]. For all plant tissues, the BF values often lower than 1.0 for $\mathrm{Cd}, \mathrm{Cu}, \mathrm{Pb}$ and $\mathrm{Zn}$. In contrast, the $\mathrm{BF}$ values of As which were extremely high in all tissues of almost all plants except 


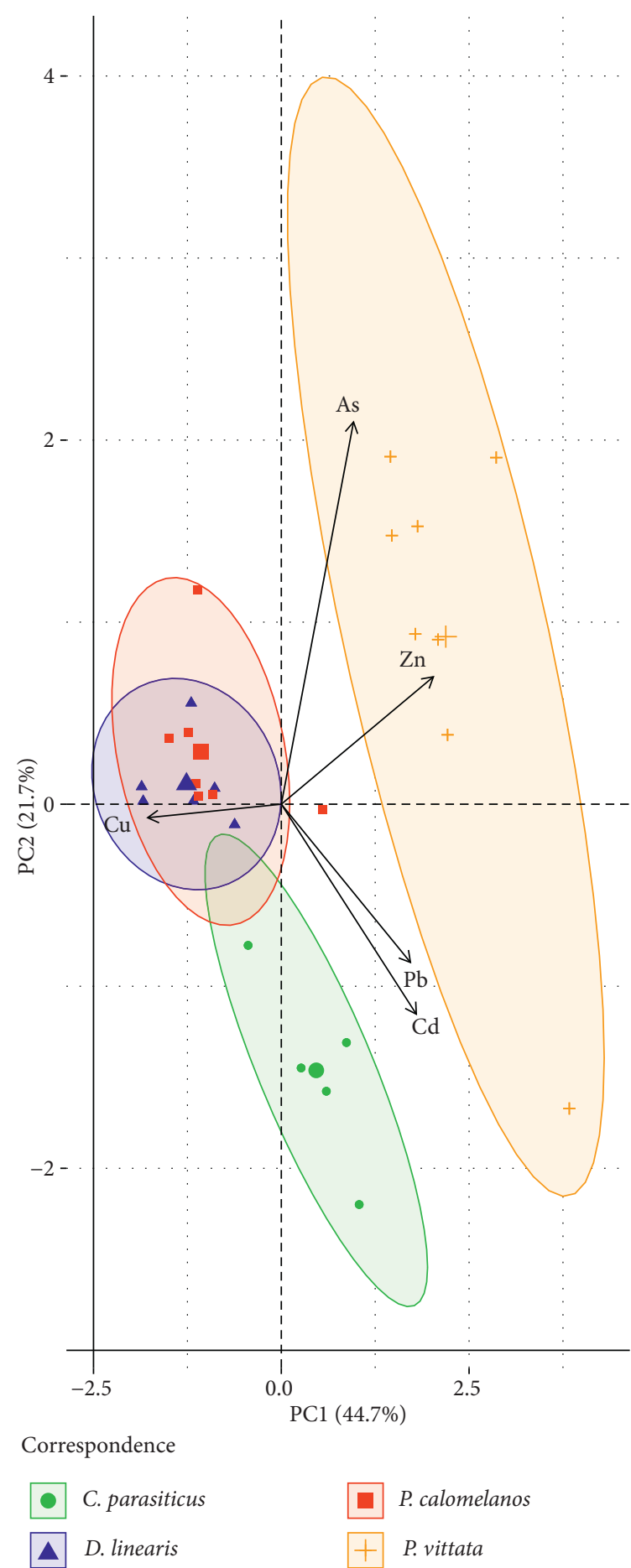

Figure 1: PCA of the concentration of $\mathrm{HMs}$ (As, $\mathrm{Cd}, \mathrm{Cu}, \mathrm{Pb}$, and $\mathrm{Zn}$ ) in 25 soil samples corresponding to 25 plants of 4 species ( $C$. parasiticus, $D$. linearis, $P$. calomelanos, and $P$. vittata). Each point displays a sample; each vector displays the level of an HM. Soil samples are colored and shaped according to different species where they were collected.

C. parasiticus with BFAs lower than 1. This indicated the higher moving ability of As from the external environment into plant tissues through the soil exposure route compared to the other 3 metals. It is also found that $P$. vittata sampled at Dong Hy possessed a higher metal bioaccumulation factor (up to 402.5) than other plants indicating its hyperaccumulating ability. There are a number of reports indicating that $P$. vittata is an As hyperaccumulator $[27,28]$ capable of translocating As and storing it in the shoots $[29,30]$.

Similarly, most shoot and root tissues of all almost plants had TF values lower than 1, except TFAs (in C. parasiticus) and TFCd (in C. parasiticus and D. linearis plant) values, which are much higher than 1 . In more detail, the maximum values of TFCd and TFAs found in shoots of $C$. parasiticus plants were 18.4 and 4.51, respectively. Furthermore, the TFmetals indices in the shoots were often higher than that in leaves of C. parasiticus and D. linearis plants, whereas higher TF metals indices were found in leaves of $P$. calomelanos and $P$. vittata. High root to shoot translocation of these metals in C. parasiticus and D. linearis indicated vital characteristics to be used in phytoextraction of these metals in shoot [31, 32]. On the other side, the results in TF and BF values of $P$. calomelanos and $P$. vittata were considered suitable for phytoextraction, which generally requires translocation of metals easily harvestable leaves tissue to remove the metal contamination from the soil without destroying soil structure and fertility $[33,34]$. In fact, plant species were judged as being suited for phytoremediation based on several criteria including wide distribution, high above-ground biomass, high bioaccumulation factors (hyperaccumulators), short life cycles, and high propagation rates [35]. Therefore, it could be concluded that $P$. vittata and $P$. calomelanos can be used in phytoremediation in mine sites of Thai Nguyen province as they were considered as native plants that meet all criteria for a hyperaccumulator.

3.3. Species-Tissue Discrimination of HMs Levels in Plants. In order to see whether there are differences in the concentration of HMs level (i.e., variables) in samples (i.e., individuals), PCA biplots where both individuals and variables are graphed on the same plot were constructed. In the first two PCs, more than $60 \%$ of the variance in the data is explained for all PCA plots. In accordance with the PCA biplot (Figure 2(a)), HM levels in 75 plant tissues were grouped in a different pattern based on species. The discrimination of these patterns indicates that four species show a different capacity in uptaking 5 mentioned HMs. The PCA biplots containing only data of HM levels in shoots or leaves showed better separation between four species (Figures 2(c) and 2(d)) while that of roots separated well 3 patterns corresponding to species D. linearis, P. calomelanos, and P. vittata (Figure 2(b)). This indicates that there is a contribution to the difference in accumulation ability among tissues on the discrimination of 75 samples based on species. This result would be useful for understanding the different translocation factors of 4 ferns calculated in Table 2. In addition, taking into account the variable vector in a PCA biplot, it can be seen that $\mathrm{Cu}$ was accumulated with a higher level in all tissue of $P$. calomelanos which confirms again the previous finding of the $\mathrm{Cu}$ accumulation ability of this fern $[13,36,37]$. In the current study, $P$. calomelanos does not show the arsenic accumulation capability, whereas many 
TABle 2: The average concentration $( \pm \mathrm{SD})$ of five HMs in plant tissues (root, shoot, and leave) from 4 species, C. parasiticus, D. linearis, $P$. calomelanos, and P. vittata, and corresponding bioaccumulation factor (BF) and translocation factor (TF).

\begin{tabular}{|c|c|c|c|c|c|c|c|c|c|c|c|c|c|c|c|c|}
\hline \multirow{2}{*}{$\begin{array}{l}\text { Plant } \\
\text { species }\end{array}$} & \multirow{2}{*}{$\begin{array}{l}\text { Plant } \\
\text { tissue }\end{array}$} & \multicolumn{3}{|c|}{ As } & \multicolumn{3}{|c|}{$\mathrm{Cd}$} & \multicolumn{3}{|c|}{$\mathrm{Cu}$} & \multicolumn{3}{|c|}{$\mathrm{Pb}$} & \multicolumn{3}{|c|}{$\mathrm{Zn}$} \\
\hline & & Conc. & $\mathrm{BF}$ & $\mathrm{TF}$ & Conc. & $\mathrm{BF}$ & $\mathrm{TF}$ & Conc. & $\mathrm{BF}$ & $\mathrm{TF}$ & Conc. & $\mathrm{BF}$ & $\mathrm{TF}$ & Conc. & $\mathrm{BF}$ & $\mathrm{TF}$ \\
\hline \multirow{3}{*}{$\begin{array}{l}\text { C. } \\
\text { parasiticus }\end{array}$} & Root & $1.19 \pm 1.77$ & & - & $.58 \pm 0.49$ & 0.29 & - & $9.7 \pm 5.92$ & 0.12 & - & & 0.01 & - & $21 \pm 73.6$ & 1.12 & - \\
\hline & & & 0.2 & 4.51 & & 0.36 & 18.4 & & 0.08 & 0.88 & & 0.01 & 1.28 & & 0.27 & 1.10 \\
\hline & & & 0.18 & 4.43 & 30 & 0.45 & 8.37 & & 0.09 & 0.81 & & 0.02 & 0.61 & 0.7 & 1.10 & 0.28 \\
\hline \multirow{3}{*}{ D. linearis } & & & & - & & & & & & - & & 21 & - & & 45 & - \\
\hline & & & & 0.32 & & 0.2 & 7.61 & & 24 & & & 05 & 0.47 & & 29 & 0.99 \\
\hline & & & 14 & 0.57 & & 0.82 & 0.44 & & 17 & 0.59 & & 0.09 & 0.25 & & 0.57 & 0.59 \\
\hline \multirow{3}{*}{$\begin{array}{l}P . \\
\text { calomelanos }\end{array}$} & & & 169 & - & & 0.97 & - & & 1.37 & - & & 0.78 & - & & .52 & - \\
\hline & & 1.8 & 102 & 0.61 & .03 & 0.26 & 0.29 & & 0.16 & 0.12 & & 0.07 & 0.10 & & 0.40 & 0.27 \\
\hline & Leave & & 229 & 1.37 & & 0.48 & 0.57 & & 0.18 & 0.17 & & 0.08 & 0.12 & & 0.83 & 0.55 \\
\hline \multirow{3}{*}{ P. vittata } & & $732 \pm 299.1$ & 403 & - & $.27 \pm 0.26$ & 0.13 & - & & 1.06 & - & & 0.88 & - & & 0.35 & - \\
\hline & & & 76 & 0.20 & & 0.0 & 0.84 & & 0. & 0.84 & & 0.19 & 0.28 & & 0.23 & 0.65 \\
\hline & & & 99.5 & 1.09 & & 0.18 & 1.49 & $6.13 \pm 3.4$ & 1.17 & 1.03 & & 0.47 & 0.59 & $267 \pm 125$ & 1.13 & 3.18 \\
\hline
\end{tabular}

studies have reported that this fern can accumulate more than $2000 \mathrm{mg} / \mathrm{kg}$ in their tissues $[12,38]$, even better than $P$. vittata [39]. However, the arsenic accumulation behavior of these two ferns changed according to field conditions, i.e., subtropical or tropical, highly or lightly contaminated soils, drought and other weeds under field conditions [40]. Other studies also reported the ability of $P$. calomelanos in $\mathrm{As}-\mathrm{Pb}$ coaccumulating $[15,41]$. In this study, the poor performance of $P$. calomelanos in HM accumulation at $\mathrm{Ha}$ Thuong, Dai Tu may be due to low concentration of $\mathrm{As}, \mathrm{Pb}, \mathrm{Cu}$ in this site, compared to Tan Long, Dong Hy where P. vittata were collected. It can also be highlighted from Figure 3 that As, $\mathrm{Pb}, \mathrm{Zn}$ were accumulated with the highest levels in $P$. vittata. This finding is consistent with the previous research conclusion that $P$. vittata is an arsenic hyperaccumulator [27], useful for the remediation of As polluted sites cocontaminated with $\mathrm{Zn}[11], \mathrm{Pb}[15,41]$, and $\mathrm{Cd}[6]$.

\subsection{Relationship between the HMs Levels in Soils and Plants.} To evaluate whether the HMs levels in soils have impact on the difference in accumulation activity of plant tissues, environmental factors (i.e., HMs levels in soils) were fitted onto the ordination represented by the principal component analysis. As a result, the significant correlation between HMs levels in soils and samples similarities of the dataset for 75 samples and the subsets of roots, shoots, and leaves, with $p$ values below 0.05 , are reported in Table 3 . For all 75 samples, the concentration of two elements $\mathrm{Zn}$ and $\mathrm{Cu}$ in soils showed a significant correlation $\left(r^{2}=0.42, p\right.$ value $<0.001$, and $r 2=0.40, p$ value $<0.001$, respectively). Furthermore, concerning the impact of HMs in soils on the sample similarities in only one tissue, these two above-mentioned variables presented more important correlations $\left(r^{2}=0.57\right.$ and $r^{2}=0.65$ in roots, $r^{2}=0.59$ and $r^{2}=0.55$ in shoots, $r^{2}=0.71$ and $r^{2}=0.59$ in leaves, respectively with all $p$ value $<0.001$ ). This suggested that the concentration of $\mathrm{Zn}$ and $\mathrm{Cu}$ in soils is most responsible for the discrimination based on species between all samples as well as roots, shoots, and leaves. The concentration of three remaining $\mathrm{HMs}$ ( $\mathrm{As}, \mathrm{Cd}, \mathrm{Pb}$ ) was less contributed to the variation in HMs accumulation of 4 weeds ( $r^{2}<0.4$ except the levels of $\mathrm{Cd}$ and $\mathrm{Pb}$ in shoots).
The correlation between the HMs levels in soils and in tissues was calculated by the Spearman method to reveal the relationship among these variables. As can be seen from Figure $4, \mathrm{~Pb}$ level in tissues correlated very strongly with As concentration in tissues $(r=0.86, p$ value $<0.001)$ which indicates there is a coaccumulation of $\mathrm{Pb}$ and $\mathrm{As}$ of these ferns. To the best our knowledge, it is the first time these two elements were found to be proportionally uptaken in plant tissues. Moreover, $\mathrm{Zn}$ concentration in tissues correlated moderately with $\mathrm{Zn}$ level in soils $(r=0.43, p$ value $<0.001)$ indicating the $\mathrm{Zn}$ accumulation capacity of 4 ferns does not depend very much on the fern species.

3.5. Antioxidant Properties of Plant Extracts. The radical scavenging capacity of the crude plant extracts was determined from the reduction in the optical absorbance due to the scavenging of DPPH and SRSA radicals activity. Our study indicated that the roots possessed a high antioxidant activity, while shoots and leaves expressed the lower DPPH scavenging effects for all four species (Figure 3). At $500 \mu \mathrm{g} /$ $\mathrm{mL}$ of concentration, most of the samples were considered to have DPPH radical scavenging activity. At a concentration of $100 \mu \mathrm{g} / \mathrm{mL}$, roots of $C$. parasiticus presented the highest $\mathrm{DPPH}$ scavenging activity with the inhibition of radicals generation value $88.1 \pm 2.61 \%$ at the concentration $100 \mu \mathrm{g} /$ $\mathrm{mL}$ (Table 4). To date, there is almost no research about the antioxidant of $C$. parasiticus except a study on the chemical composition of this fern that reveals the presence of some coumarin-chalcone hybrids in this weed [42]. Concerning SRSA scavenging activity, only the roots of $P$. vittata were considered to show an inhibitory effect on the O2-generation (SC\% of $54.4 \pm 5.81 \%$ ). In this study, two different approaches were applied to measure the scavenging capacity against stable, nonbiological radicals and against specific ROS/RNS. Two levels of screening were applied to see whether the antioxidant properties of these weeds can be explained by different mechanisms related to enzymatic (SRSA assay) and nonenzymatic (DPPH assay) [43]. From the applied point of view, this property opens the way to benefit these ferns as phytosource of natural antioxidants that could be used in the chemical catalyst, food, 


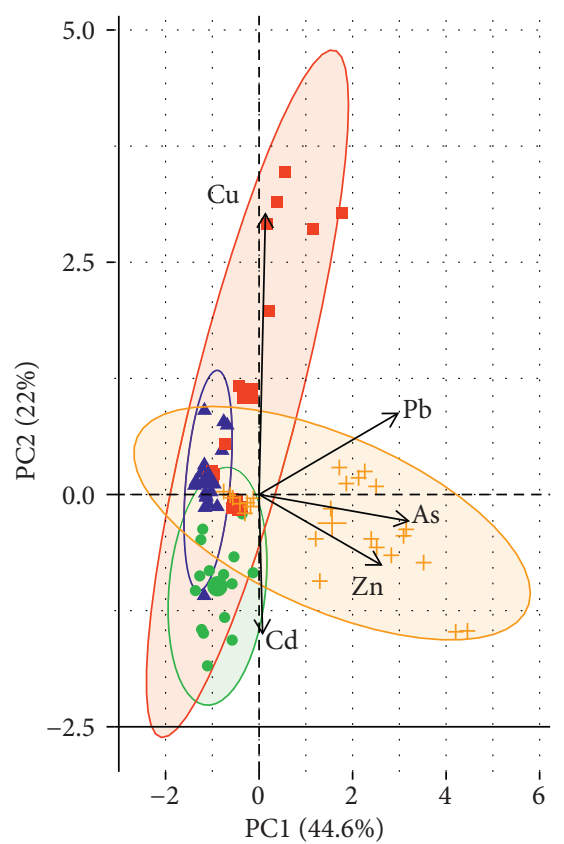

Species

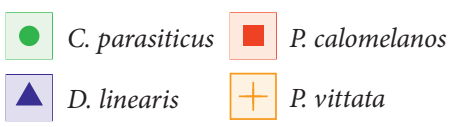

(a)

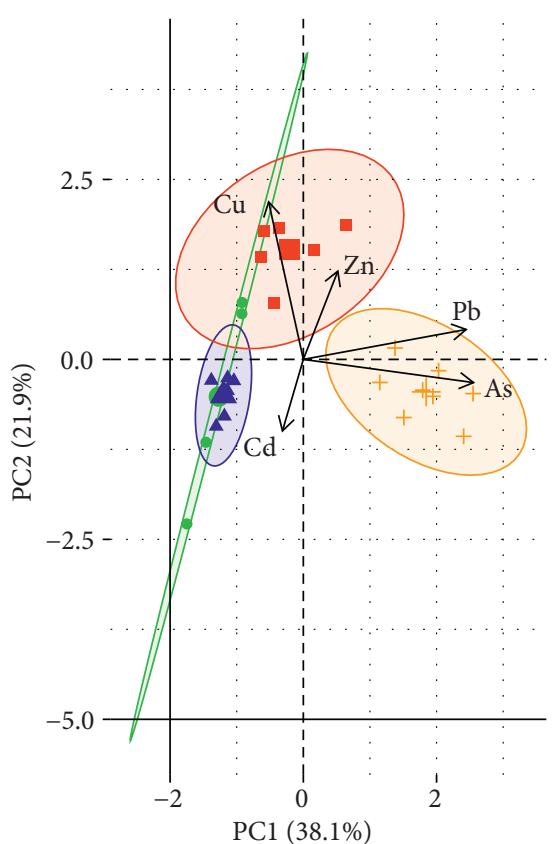

Species

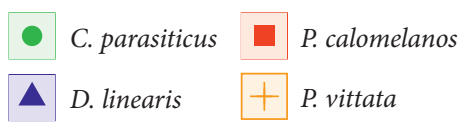

(b)

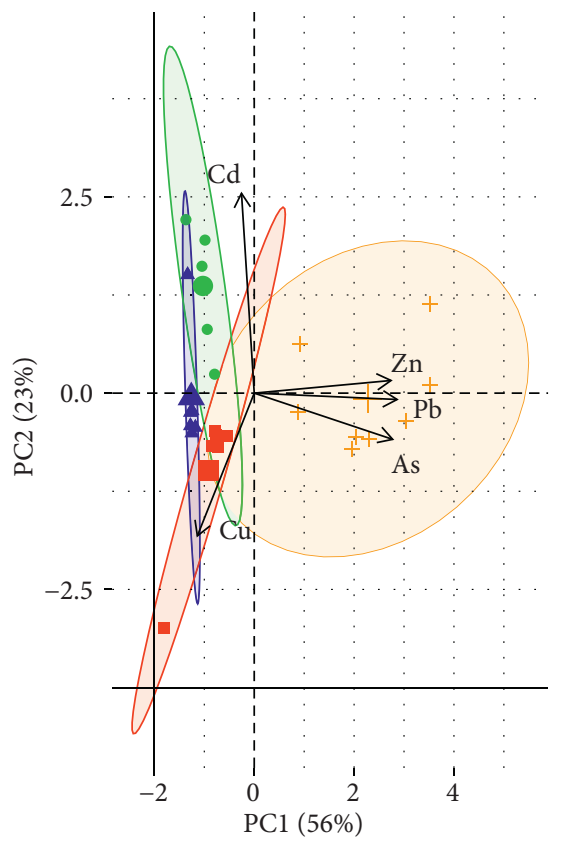

Species

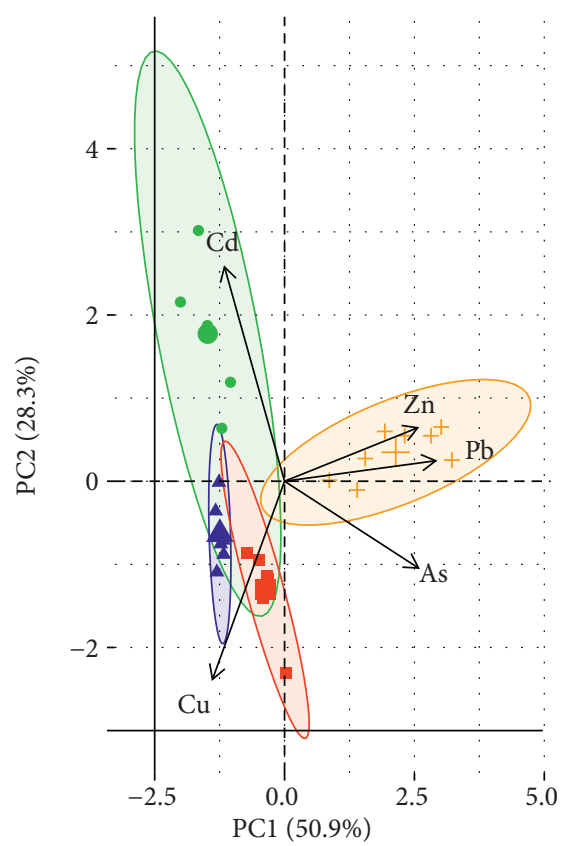

Species

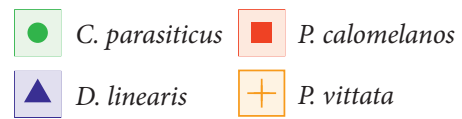

(c)

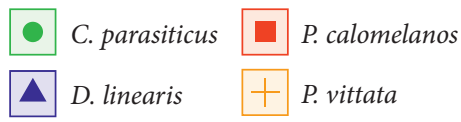

(d)

Figure 2: Principal component analysis of HM levels in 75 samples (3a), in 25 roots (3b), in 25 shoots (3c), and in 25 leaves (3d) from four species C. parasiticus, D. linearis, P. calomelanos, and P. vittata. Samples are colored and shaped according to different species. The length of the HM vector shows how high the concentration of these HMs levels is in the samples where this vector is directed toward. (a) All tissues, (b) roots, (c) shoots, and (d) leaves. 


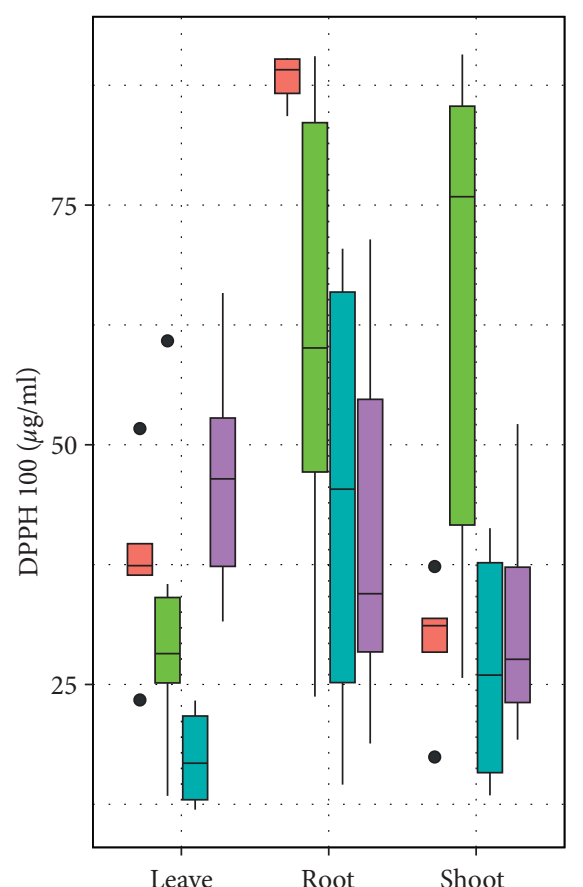

Species

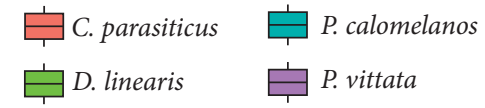

(a)

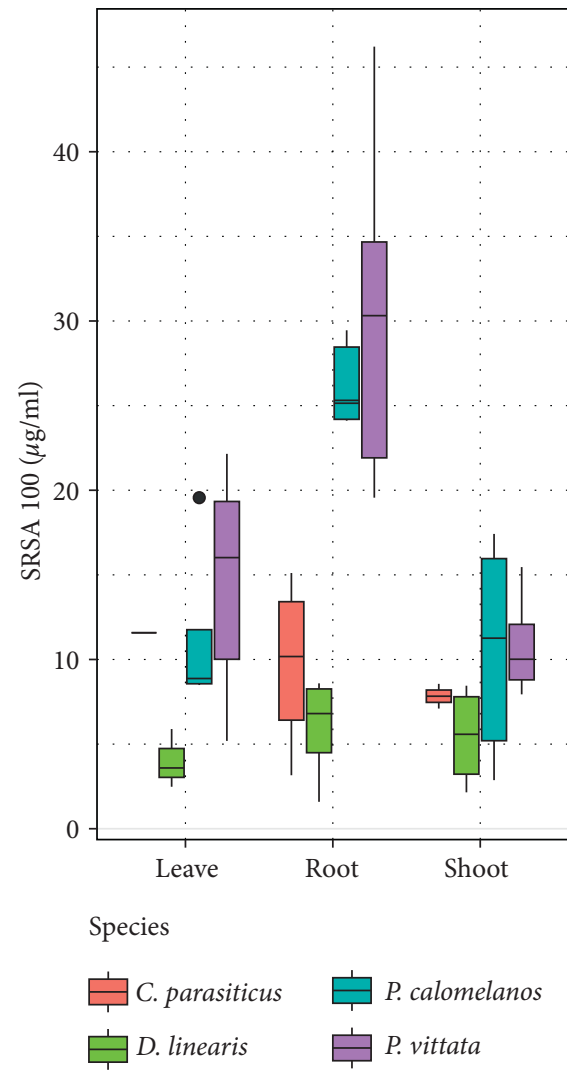

(c)

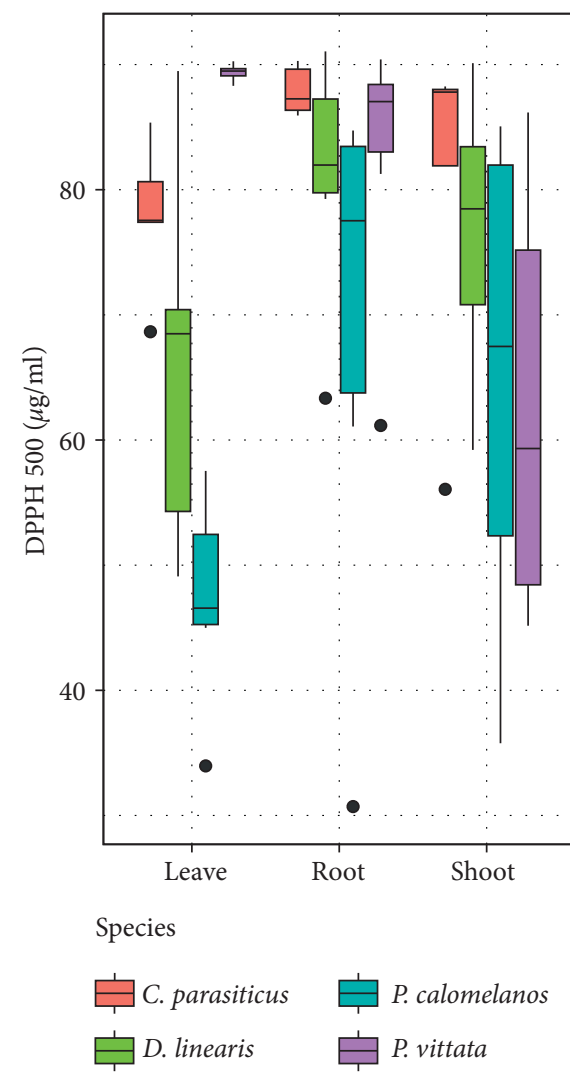

(b)

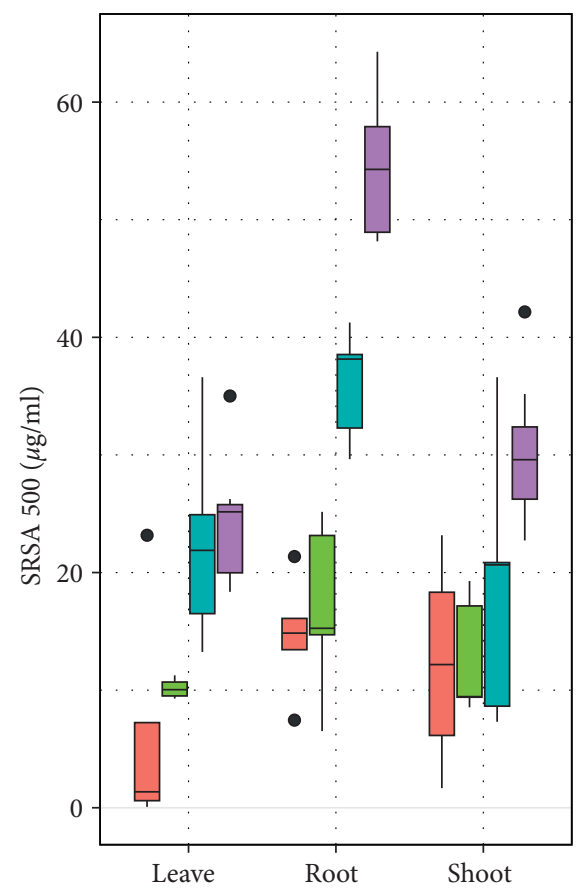

Species

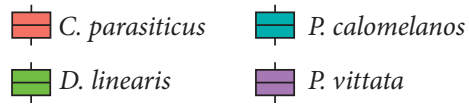

(d)

FIgURE 3: Boxplots of the DPPH and SRSA scavenging inhibition of leaves, roots, and shoots from 4 studied ferns. 
TABLE 3: The correlation coefficient of 5 environmental factors on the HMs in plant tissues, roots, shoots, and leaves was calculated by envfit function in vegan R-package.

\begin{tabular}{lcccccccc}
\hline & \multicolumn{2}{c}{ All tissue $n=75$} & \multicolumn{2}{c}{ Root $n=25$} & \multicolumn{2}{c}{ Shoot $n=25$} & \multicolumn{2}{c}{ Leave $n=25$} \\
& $r 2$ & $p$ & $r 2$ & $p$ & $r 2$ & $p$ & $p$ \\
\hline $\mathrm{Cu}$ & 0.40 & $p<0.001$ & 0.65 & $p<0.001$ & 0.55 & $p<0.001$ & 0.59 \\
$\mathrm{Zn}$ & 0.42 & $p<0.001$ & 0.57 & $p<0.001$ & 0.59 & $p<0.001$ & 0.71 & $p<0.001$ \\
$\mathrm{As}$ & 0.18 & 0.002 & 0.03 & 0.72 & 0.37 & 0.008 & 0.34 & 0.009 \\
$\mathrm{Cd}$ & 0.30 & $p<0.001$ & 0.39 & 0.007 & 0.44 & 0.005 & 0.35 \\
$\mathrm{~Pb}$ & 0.10 & 0.036 & 0.13 & 0.24 & 0.45 & 0.003 & 0.12 \\
\hline
\end{tabular}

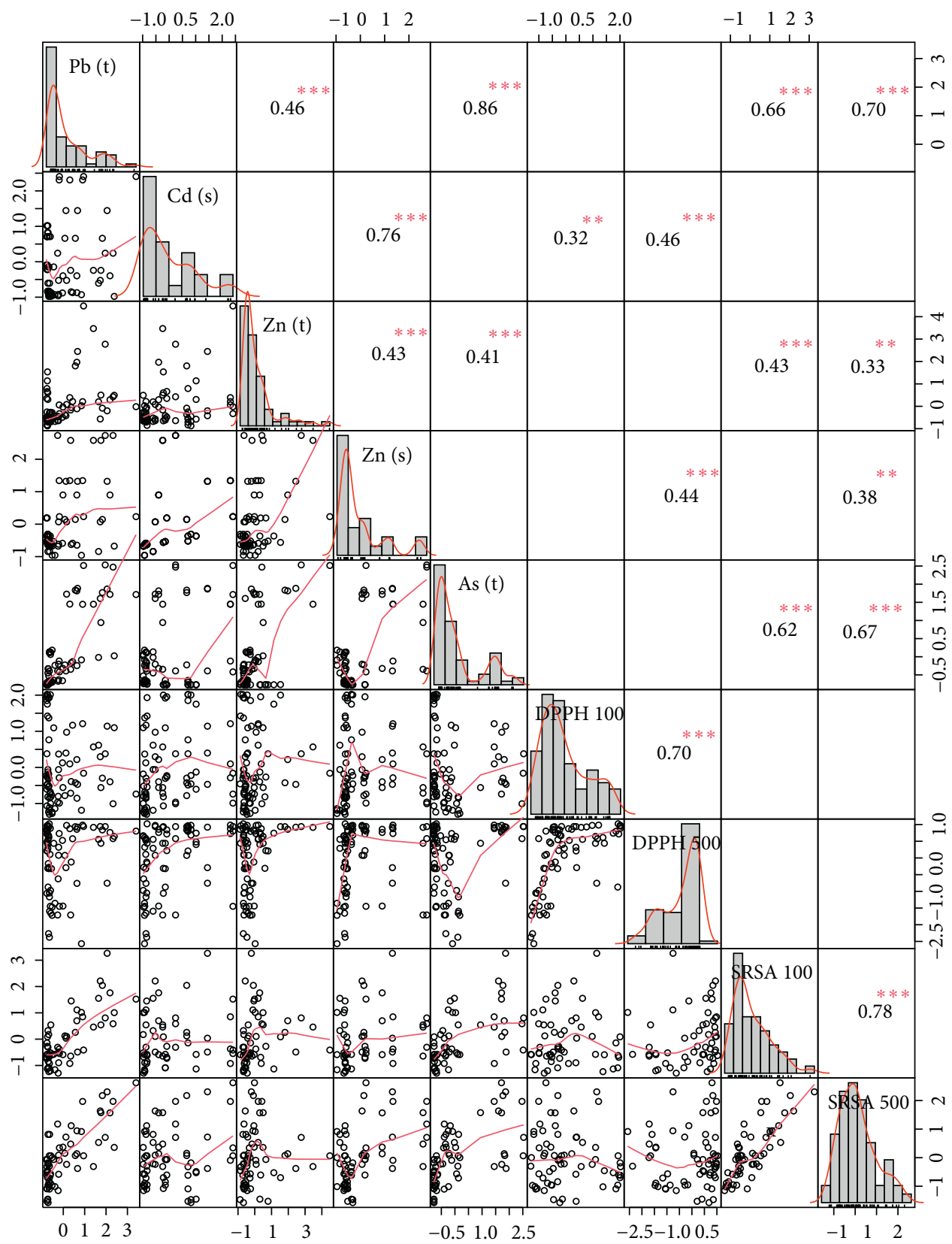

Figure 4: The significant pair to pair correlation of nine variables including $\mathrm{As}, \mathrm{Pb}, \mathrm{Zn}$ concentration in tissue, $\mathrm{Zn}$ concentration on soil, DPPH scavenging activity at $100 \mu \mathrm{g} / \mathrm{mL}$ and $500 \mu \mathrm{g} / \mathrm{mL}$, SRSA scavenging activity at $100 \mu \mathrm{g} / \mathrm{mL}$ and $500 \mu \mathrm{g} / \mathrm{mL}$. The distribution of each variable is shown on the diagonal. On the bottom of the diagonal, the bivariate scatter plots with a fitted line are displayed. On the top of the diagonal, the value of the correlation plus the significance level is denoted as stars. Each significance level is associated with a symbol: $* * * p$ value $<0.001, * * p$ value $<0.01$, and $* p$ value $<0.05$. The Pearson method was used to compute the correlation coefficient. 
TABLE 4: DPPH scavenging capacity (SC\%) of the plant extracts.

\begin{tabular}{|c|c|c|c|c|c|}
\hline Plant species & Plant tissues & DPPH SC\% at $100 \mu \mathrm{g} / \mathrm{mL}$ & $\mathrm{DPPH}$ SC $\%$ at $500 \mu \mathrm{g} / \mathrm{mL}$ & SRSA SC $\%$ at $100 \mu \mathrm{g} / \mathrm{mL}$ & SRSA SC $\%$ at $500 \mu \mathrm{g} / \mathrm{mL}$ \\
\hline \multirow{3}{*}{ C. parasiticus } & Roots & $88.1 \pm 2.61$ & $87.9 \pm 1.96$ & $9.65 \pm 5.38$ & $14.6 \pm 5.01$ \\
\hline & Shoots & $29.2 \pm 7.34$ & $80.4 \pm 13.9$ & $7.83 \pm 1.03$ & $12.3 \pm 9.53$ \\
\hline & Leaves & $37.7 \pm 10.1$ & $77.9 \pm 6.10$ & $11.6 \pm 0.00$ & $6.48 \pm 11.1$ \\
\hline \multirow{3}{*}{ D. linearis } & Roots & $61.5 \pm 26.1$ & $81.1 \pm 9.79$ & $5.94 \pm 3.21$ & $17.0 \pm 7.46$ \\
\hline & Shoots & $64.5 \pm 28.9$ & $76.6 \pm 11.1$ & $5.44 \pm 3.05$ & $12.8 \pm 5.05$ \\
\hline & Leaves & $31.8 \pm 16.0$ & $66.0 \pm 15.1$ & $3.99 \pm 1.74$ & $10.1 \pm 0.90$ \\
\hline \multirow{3}{*}{ P. calomelanos } & Roots & $44.5 \pm 24.2$ & $69.2 \pm 21.0$ & $26.3 \pm 2.51$ & $36.0 \pm 4.82$ \\
\hline & Shoots & $26.8 \pm 12.9$ & $65.0 \pm 20.2$ & $10.5 \pm 6.41$ & $18.8 \pm 11.8$ \\
\hline & Leaves & $17.3 \pm 5.04$ & $47.3 \pm 8.22$ & $11.4 \pm 5.41$ & $22.4 \pm 8.39$ \\
\hline \multirow{3}{*}{ P. vittata } & Roots & $41.7 \pm 20.0$ & $83.5 \pm 9.53$ & $29.9 \pm 9.13$ & $54.4 \pm 5.81$ \\
\hline & Shoots & $31.0 \pm 11.4$ & $61.9 \pm 16.3$ & $10.8 \pm 2.81$ & $30.3 \pm 6.11$ \\
\hline & Leaves & $46.2 \pm 11.8$ & $89.3 \pm 0.63$ & $14.9 \pm 6.04$ & $24.3 \pm 5.67$ \\
\hline Ascorbic acid & - & 91.3 & - & - & - \\
\hline Catechin & - & - & - & 48.7 & - \\
\hline
\end{tabular}

nutraceuticals, cosmetic, and pharmaceutical industries, thereby restricting the use of synthetic antioxidants.

3.6. Relationship between HM Level in Soil and in Plant Tissue and Their Antioxidant Activity. In order to investigate whether HMs in soils and HMs in tissues can affect the antioxidant activity of plants, we analyzed the relationship between the concentrations of five metals in soil and plant samples and the percentages of DPPH and SRSA scavenging of 25 plants growing in these soils. Pair to pair correlations among 14 variables were calculated by the Spearman method. The correlation coefficient was calculated as the statistical measurement of how strong a linear relationship of the paired data is. Taking into consideration the significant correlations $(p$ value $<0.01)$ and important correlations that were contributed by antioxidant activities, the simplified pairwise correlations between 5 variables $(\mathrm{Pb}$ in tissues, $\mathrm{Cd}$ in soils, $\mathrm{Zn}$ in tissues, $\mathrm{Zn}$ in soils, and $\mathrm{As}$ in tissues) and 4 antioxidant variables (SC\% DPPH at 100 and $500 \mu \mathrm{g} / \mathrm{mL} \mathrm{SC} \%$ SRSA at 100 and $500 \mu \mathrm{g} / \mathrm{mL}$ ) were shown in Figure 4. Noticeably, the concentration of As in tissues was proportional to both SRSA scavenging activity at 100 and $500 \mu \mathrm{g} / \mathrm{mL}(r=0.62$ and $r=0.67$, respectively, $p<0.001)$ but not correlated significantly with SC\% DPPH. This finding has been consistent with the previous study of Cao et al., 2004, which showed that at low levels of As exposure (0-20 mg/kg), enzymatic antioxidants (which may contribute to SRSA activity) play a more important role in As detoxification than nonenzymatic antioxidants (which may contribute to DPPH activity) in P. vittata [44]. By other research, $P$. calomelanos also presented a remarkable change in amino acid levels in As-treated plants, including those related to the biosynthesis of enzymatic antioxidants of this weed [9]. Similarly, it was also observed that $\mathrm{Pb}$ concentration in tissues correlated significantly and strongly to SC\% of SRSA at two studied concentrations $(r=0.66, p$ value $<0.001$ and $r=0.70, p$ value $<0.001$, respectively) while did not correlate to SC\% of DPPH. This allows hypothesizing that the excess of $\mathrm{Pb}$ accumulation significantly enhanced the synthesis of some enzymatic antioxidants in plants, thus induced the antioxidant activity of plants.

\section{Conclusion}

This study firstly showed the investigation of HM concentrations in soils that had a significant variation according to mining soils and corresponding plant types. As accumulated at high levels in soils and plant tissues (shoot, roots, leaves). $\mathrm{Cd}$ had a strong cocontamination relationship with other metals $\mathrm{As}, \mathrm{Zn}, \mathrm{Pb}$ according to high Spearman values (from 0.37 to 0.76$)$. Cu contaminated in Dai Tu district and had a low ability to cocontaminated with four other HMs. For all weeds, with $\mathrm{BF}$ and TF values, almost lower than $1, \mathrm{Cu}, \mathrm{Zn}$, $\mathrm{Pb}$, and $\mathrm{Cd}$ had limited ability to uptake in plant tissues. In addition, the distribution or discrimination of HM followed the different species, tissues, and soil sampling regions. Indeed, it is found that the roots of $P$. vittata of $C$. parasiticus possess the antioxidant activity via DPPH and SRSA radical scavenging assay, respectively. Therefore, the correlation between antioxidant activity of plants and HMs content has opened a prospect in the identification of hyperaccumulator species with high potential in pharmaceutical as well as phytoremediation research.

\section{Data Availability}

The data used to support the findings of this study are included within the article.

\section{Conflicts of Interest}

The authors declare that there are no conflicts of interest regarding the publication of this paper.

\section{Acknowledgments}

This research was funded by the Vietnam National Foundation for Science and Technology Development (NAFOSTED) under grant no. 106.02-2017.30. The corresponding authors would like to thank Dr. Tran Thi Thanh Tam, Department of Life Sciences, University of Science and Technology of Hanoi, Vietnam Academy of Science and Technology, for her advice in the statistical analysis part. The authors also gratefully acknowledge Laboratoire Mixte 
International "Drug Resistance in South East Asia” (LMIDRISA) for supporting the repair fee of the microplate reader in an urgent situation.

\section{Supplementary Materials}

Table S1: description of sampling sites. Figure S1: the Spearman indices indicate the correlation of heavy metals' cocontamination in soils. (Supplementary Materials)

\section{References}

[1] L. Sun, X. Liao, X. Yan, G. Zhu, and D. Ma, "Evaluation of heavy metal and polycyclic aromatic hydrocarbons accumulation in plants from typical industrial sites: potential candidate in phytoremediation for co-contamination," Environmental Science and Pollution Research, vol. 21, pp. 12494-12504, 2014.

[2] N. K. Chu, V. K. Nguyen, D. B. Nguyen et al., "Arsenic and heavy metal concentrations in agricultural soils around tin and tungsten mines in the dai tu district, n. Vietnam," Water Air Soil and Pollution, vol. 197, no. 1-4, pp. 75-89, 2009.

[3] V. B. Nguyen, D. Q. Nguyen, M. Q. Vu, and Q. T. Le, "The heavy metal distribution in the soil and water of Son Duong Sn mine," Journal of Earth Science, vol. 22, pp. 134-139, 2000.

[4] A. Nguyen, "The soil pollution associated with mining in vietnam," in Proceedings of Contaminated Agricultural Land Management and Remediation Workshop, Hanoi, Vietnam, December 2005.

[5] B. T. Anh, D. D. Kim, T. V. Tua, N. T. Kien, and D. T. Anh, "Phytoremediation potential of indigenous plants from thai nguyen province, Vietnam," Journal of Environmental Biology, vol. 32, no. 2, pp. 257-262, 2011.

[6] X. Xiao, T. Chen, Z. An et al., "Potential of Pteris vittata L. for phytoremediation of sites co-contaminated with cadmium and arsenic: the tolerance and accumulation," Journal of Environmental Sciences, vol. 20, no. 1, pp. 62-67, 2008.

[7] Vietnam Ministry of Natural Resources and Environment, QCVN 03-MT:2015/BTNMT-National Technical Regulation on the Allowable Limits of Heavy Metals in the Soils, Vietnam Ministry of Natural Resources and Environment, Hanoi, Vietnam, in Vietnamese, 2015.

[8] T. H. Nguyen, M. Sakakibara, S. Sano, and T. N. Mai, "Uptake of metals and metalloids by plants growing in a lead-zinc mine area, Northern Vietnam," Journal of Hazardous Materials, vol. 86, no. 2, pp. 1384-1391, 2011.

[9] N. V. Campos, T. O. Araújo, S. Arcanjo-Silva, L. Freitas-Silva, A. A. Azevedo, and A. Nunes-Nesi, "Arsenic hyperaccumulation induces metabolic reprogramming in Pityrogramma calomelanosto reduce oxidative stress," Physiologia Plantarum, vol. 157, no. 2, pp. 135-146, 2016.

[10] H. Sarma, "Metal hyperaccumulation in plants: a review focusing on phytoremediation technology," Journal of Environmental Science and Technology, vol. 4, no. 2, pp. 118-138, 2011.

[11] Z.-Z. An, Z.-C. Huang, M. Lei, X.-Y. Liao, Y.-M. Zheng, and T.-B. Chen, "Zinc tolerance and accumulation in Pteris vittata L. and its potential for phytoremediation of $\mathrm{Zn}^{-}$and Ascontaminated soil," Chemosphere, vol. 62, no. 5, pp. 796-802, 2006.

[12] T. K. A. Bui, D. K. Dang, T. K. Nguyen, N. M. Nguyen, Q. T. Nguyen, and H. C. Nguyen, "Phytoremediation of heavy metal polluted soil and water in Vietnam," Journal of Vietnamese Environment, vol. 6, no. 1, pp. 47-51, 2014.
[13] Z. C. Win, L. J. L. Diaz, T. R. Perez, and K. Nakasaki, "Phytoremediation of heavy metal contaminated wastes from small-scale gold mining using Pityrogramma calomelanos," E3S Web of Conferences, vol. 148, 2020.

[14] H. B. Wang, Z. H. Ye, W. S. Shu, W. C. Li, M. H. Wong, and C. Y. Lan, "Arsenic uptake and accumulation in fern species growing at arsenic-contaminated sites of southern China: field surveys," International Journal of Phytoremediation, vol. 8, no. 1, pp. 1-11, 2006.

[15] P. Soongsombat, M. Kruatrachue, R. Chaiyarat, P. Pokethitiyook, and C. Ngernsansaruay, "Lead tolerance and accumulation Inpteris Vittata and Pityrogramma calomelanos and their potential for phytoremediation of lead-contaminated soil," International Journal of Phytoremediation, vol. 11, no. 4, pp. 396-412, 2009.

[16] T. T. Huong, N. X. Cuong, L. H. Tram et al., "A new prenylated aurone from Artocarpus Altilis," Journal of Asian Natural Products Research, vol. 14, no. 9, pp. 923-928, 2012.

[17] J.-H. Lee and J.-S. Park, "Antioxidant activities of solventextracted fractions from Kummerowia Striata (thunb.) schindl," Indian Journal of Science and Technology, vol. 8, no. 1, pp. 28-31, 2015.

[18] R Core Team, R: A Language and Environment for Statistical Computing, R Foundation for Statistical Computing, Vienna, Austria, 2018, https://www.R-project.org/.

[19] S. Le, J. Josse, and F. Husson, "Facto mine R: an R package for multivariate analysis," Journal of Statistical Software, vol. 25, no. 1, pp. 1-18, 2008.

[20] A. Kassambara and M. Fabian, "Factoextra: extract and visualize the results of multivariate data analyses," 2020, https:// CRAN.R-project.org/package=factoextra.

[21] J. Oksanen, F. G. Blanchet, F. Michael et al., "Vegan: community ecology package. R package version 2.4-3," 2017, https://CRAN.R-project.org/package=vegan.

[22] G. P. Brian, C. Pete, B. Kris, B. Ross, U. Joshua, and Z. Eric, "Performanceanalytics: econometric tools for performance and risk analysis," R Package Version, vol. 107, no. 1, p. 3541, 2014.

[23] J. Luo, W. He, X. Xing, J. Wu, X. W. Sophie Gu, and X. W. S. Gu, "The variation of metal fractions and potential environmental risk in phytoremediating multiple metal polluted soils using Noccaea Caerulescens assisted by LED lights," Chemosphere, vol. 227, pp. 462-469, 2019.

[24] C. E. Martínez and H. L. Motto, "Solubility of lead, zinc and copper added to mineral soils," Environmental Pollution, vol. 107, p. 1, 2000.

[25] R. Malik, S. Husain, and I. Nazir, "Heavy metal contamination and accumulation in soil and wild plant species from industrial area of islamabad, Pakistan," Journal of Botany, vol. 42, pp. 291-301, 2010.

[26] G. Arumugam, R. Rajendran, A. Ganesan, and R. Sethu, "Bioaccumulation and translocation of heavy metals in mangrove rhizosphere sediments to tissues of Avicenia marina-a field study from tropical mangrove forest," Environmental Nanotechnology, Monitoring \& Management, vol. 10, pp. 272-279, 2018.

[27] L. Q. Ma, K. M. Komar, C. Tu, W. Zhang, and Y. Cai, “A fern that hyperaccumulates arsenic," Nature, vol. 409, no. 6820, p. $579,2001$.

[28] T. Kennelley, C. Wei, Z. Huang, Q. Huang, Q. Lu, and Z. Fan, "Arsenic hyperaccumulator Pteris vittata L. and its arsenic accumulation," Chinese Science Bulletin, vol. 47, no. 11, pp. 902-905, 2002. 
[29] S. P. McGrath, F. J. Zhao, and E. Lombi, "Plant and rhizosphere processes involved in phytoremediation of metalcontaminated soils," Plant and Soil, vol. 232, no. 1, pp. 207-214, 2001.

[30] L. Ozturk, S. Karanlik, F. Ozkutlu, I. Cakmak, and L. V. Kochian, "Shoot biomass and zinc/cadmium uptake for hyperaccumulator and non accumulator thlaspi species in response to growth on a zinc-deficient calcareous soil," Plant Science, vol. 164, pp. 1095-101, 2003.

[31] M. Ghosh and S. Singh, "A review on phytoremediation of heavy metals and utilization of its byproducts," Applied Ecology and Environmental Research, vol. 3, no. 1, 2018.

[32] J. L. Díez, P. Kidd, and C. M. Monterroso, "A biogeochemical study of the trás-os-montes region (NE portugal): possible species for plant-based soil remediation technologies," The Science of the Total Environment, vol. 354, no. 2, pp. 265-277, 2006.

[33] M. Ghosh and S. Singh, "A review on phytoremediation of heavy metals and utilization of its byproducts," Applied Ecology and Environmental Research, vol. 3, pp. 1-18, 2005.

[34] J. Yoon and X. Cao, Q. Zhou, "Accumulation of Pb, Cu, and $\mathrm{Zn}$ in native plants growing on a contaminated Florida site," Science of The Total Environment, vol. 368, no. 2, pp. 456-464, 2006.

[35] A. Ma, G. Arun, S. Vinothkumar, and R. Rajaram, "Bioaccumulation and translocation efficacy of heavy metals by Rhizophora mucronata from tropical mangrove ecosystem, southeast coast of India," Ecohydrology \& Hydrobiology, vol. 19, no. 1, pp. 66-74, 201.

[36] F. Perlatti, T. O. Ferreira, R. E. Romero, M. C. G. Costa, and X. L. Otero, "Copper accumulation and changes in soil physical-chemical properties promoted by native plants in an abandoned mine site in northeastern Brazil: implications for restoration of mine sites," Ecological Engineering, vol. 82, pp. 103-111, 2015.

[37] D. Dahilan, "Assessment of copper in Pityrogramma calomelanos," Philippine Journal of Science, vol. 146, no. 3, pp. 331-338, 2017.

[38] K. Francesconi, P. Visoottiviseth, W. Sridokchan, and W. Goessler, "Arsenic species in an arsenic hyperaccumulating fern, Pityrogramma calomelanos: a potential phytoremediator of arsenic-contaminated soils," Science of The Total Environment, vol. 284, no. 1, pp. 27-35, 2002.

[39] P. Visoottiviseth, K. Francesconi, and W. Sridokchan, "The potential of thai indigenous plant species for the phytoremediation of arsenic contaminated land," Environmental Pollution, vol. 118, no. 3, pp. 453-461, 2002.

[40] N. K. Niazi, B. Singh, L. Van Zwieten, and A. G. Kachenko, "Phytoremediation of an arsenic-contaminated site using Pteris vittata L. and Pityrogramma calomelanos var. austroamericana: a long-term study," Environmental Science and Pollution Research, vol. 19, no. 8, pp. 3506-3515, 2012.

[41] A. L. Salido, K. L. Hasty, J.-M. Lim, and D. J. Butcher, "Phytoremediation of arsenic and lead in contaminated soil using Chinese brake ferns (Pteris vittata) and Indian mustard (Brassica juncea)," International Journal of Phytoremediation, vol. 5, no. 2, pp. 89-103, 2003.

[42] H. Wei, J. Ruan, and X. Zhang, "Coumarin-chalcone hybrids: promising agents with diverse pharmacological properties," Royal Society of Chemistry Advances, vol. 6, pp. 10846-10860, 2016.

[43] L. M. Magalhães, M. A. Segundo, S. Reis, and J. L. F. C. Lima, "Methodological aspects about in vitro evaluation of antioxidant properties," Analytica Chimica Acta, vol. 613, pp. 1-19, 2008.

[44] X. Cao, L. Q. Ma, and C. Tu, "Antioxidative responses to arsenic in the arsenic-hyperaccumulator Chinese brake fern (Pteris vittata L.)," Environmental Pollution, vol. 128, pp. 317-325, 2004. 